\title{
Short synthesis of 2,3,4,5-tetrahydrocytisine
}

\author{
Pál Scheiber* and Péter Nemes \\ Department of Chemistry, School of Veterinary Medicine, Szent István University, \\ 1400 Budapest, P. O. Box 2, Hungary \\ E-mail:scheiber.pal@aotk.szie.hu
}

\section{Dedicated to Professor Csaba Szántay on the occasion of his 80th birthday}

\begin{abstract}
2,3,4,5-Tetrahydrocytisine (5) was synthesized from quinolizidine-2,6-dione in three steps and acceptable yield.

Keywords: Cytisine, quinolizidine-2,6-dione, Mannich condensation, ( \pm )-2,3,4,5tetrahydrocytisine
\end{abstract}

\section{Introduction}

Due to its ability to affect the nicotinic cholinergic receptors ${ }^{1}$ selectively, cytisine $\mathbf{1}$, a well known and widespread representative of quinolizidine alkaloids ${ }^{2}$ of family Leguminosae has attracted considerable attention in the pharmacology $y^{3,4}$ and in the synthetic chemistry, as well. Especially, the recent results ${ }^{5,6,7,8}$ of pharmacological studies stimulated the synthetic research considerably, inspiring the development of new drugs, e.g. in smoking cessation. As a result of the numerous trials some different strategies have been elaborated towards its total synthesis starting mainly from properly substituted pyridines ${ }^{9,10,11}$, piperidines $^{12}$ or bispidines ${ }^{13}$, affording the target molecule at the end of multistep procedures in poor or moderate yields. These methods have been surveyed in a comparative manner in an excellent review published recently. ${ }^{14}$

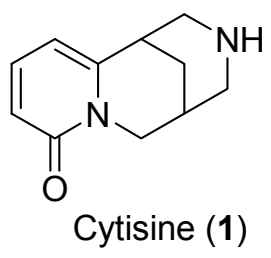

Some saturated compounds including the 3,7-diazatricyclic moiety of cytisine were synthesized from 2 -quinolizidone in our laboratory some years ago. ${ }^{15}$ Our experiments to convert 
these saturated diazatricyclics to cytisine proved, however, unsuccessful, though a wide scale of oxidizing agents, e.g. potassium hexacyanoferrate(III), sodium dichromate, mercury(II) acetate, 2,3-dichloro-5,6-dicyano-1,4-benzoquinone (DCCQ), was tried to effect the regioselective tertiary amine $\rightarrow$ lactam oxidation. Unfortunately, no satisfactory selectivity was observed, and the very complex mixtures obtained in these oxidative transformations made this strategy useless.

\section{Results and Discussion}

Due to the difficulties mentioned above quinolizidine-2,6-dione (2), a starting compound including the lactam functionality, was subjected to a double Mannich condensation used successfully in our previous work. ${ }^{15}$

The key intermediate 2 was synthesized using the biomimetic $\alpha$-acylimmonium cyclization method. ${ }^{16}$ Thus, glutarimide was alkylated with 3-butyn-1-ol in a Mitsunobu protocol and reduced with L-Selectride ${ }^{R}$, followed by treatment with formic acid, to give the desired product in an acceptable yield. An alternative synthetic route was also used to obtain 2 . The 2-piperidone diester available from simple chemicals in some steps ${ }^{17}$ was cyclized, hydrolyzed and decarboxylated in a usual Dieckmann sequence to produce $\mathbf{2}$ on a multigram scale without need of the chromatographic purification (Scheme 1).
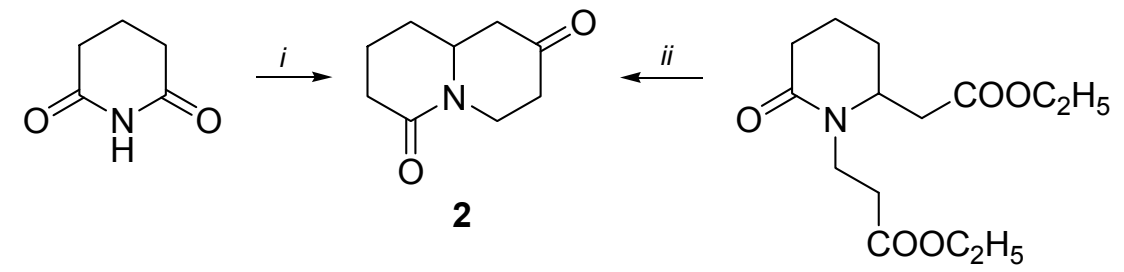

$i$, acylimmonium cyclization; ii, Dieckmann condensation, hydrolysis, decarboxylation

Scheme 1. Synthesis of the key intermediate 2.

The double Mannich condensation of 2 with formaldehyde and methylamine furnished the ketones 3a,b in good yield (Scheme 2). The reduction of the C(13) carbonyl group of $\mathbf{3 b}$ was effected through reduction of its tosylhydrazone with sodium cyanoborohydride in sulfolan dimethyl formamide mixture to yield 4. The classical Wolff-Kishner procedure gave the same product without any observable damage of the lactam group and in a higher yield (Scheme 3). Removal of the benzyl group of $\mathbf{4}$ in the usual way (hydrogenation with palladium/charcoal) resulted in 2,3,4,5-tetrahydrocytisine (5) as a racemic mixture. 

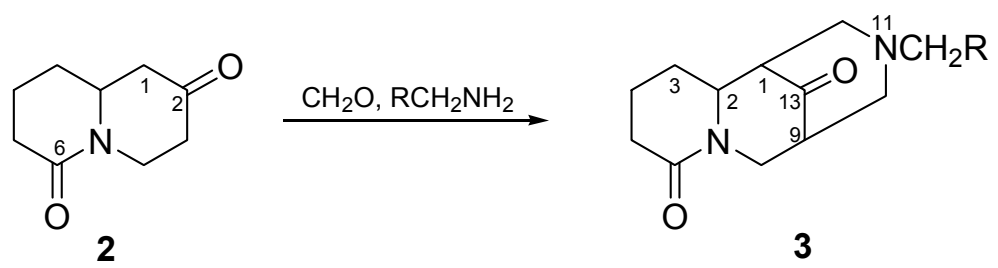

$$
\begin{aligned}
& \text { a } \mathrm{R}=\mathrm{H} \\
& \text { b } \mathrm{R}=\mathrm{C}_{6} \mathrm{H}_{5}
\end{aligned}
$$

Scheme 2. The double Mannich condensation.

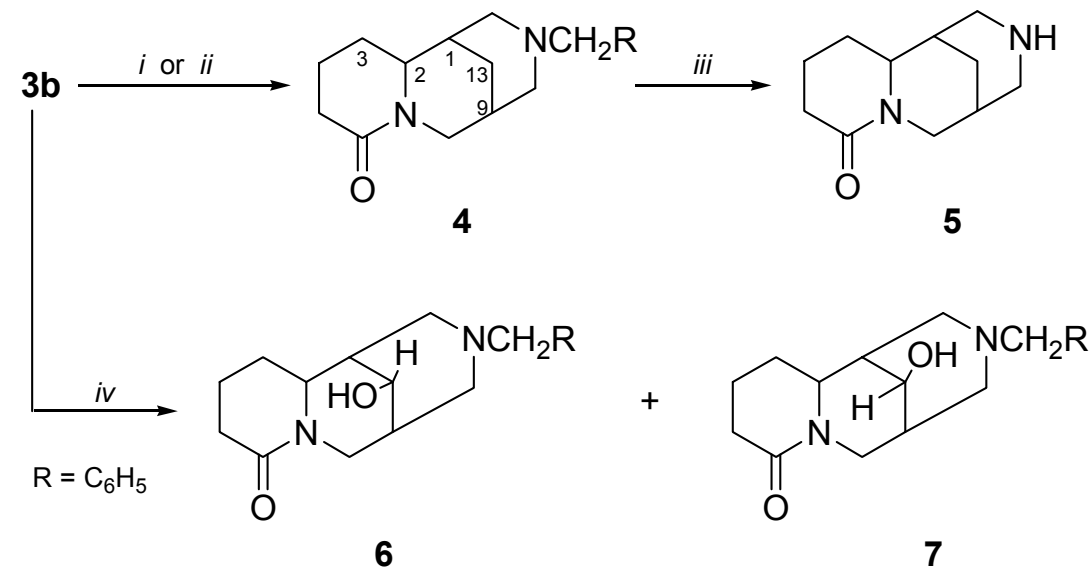

Reagents

i, Tos $\mathrm{NHNH}_{2} /$ methanol, then $\mathrm{NaBH}_{3} \mathrm{CN} ;$ ii, $\mathrm{N}_{2} \mathrm{H}_{4}, \mathrm{KOH}$, ethylene glycol, $180^{\circ} \mathrm{C}$; iii, $\mathrm{Pd} / \mathrm{C}$; iv, $\mathrm{NaBH}_{4}$, methanol

Scheme 3. Transformations of $\mathbf{3 b}$.

Reduction of the ketolactam $\mathbf{3 b}$ with sodium borohydride led to the formation of an isomeric pair of hydroxylactams 6 ( $\alpha$ isomer) and 7 ( $\beta$ isomer) in a ratio $2 / 8$. Based on a previous NMR signal assignment ${ }^{15,18}$ the steric position of the $\mathrm{C}(13)-\mathrm{OH}$ group was determined by ${ }^{13} \mathrm{C} \mathrm{NMR}$ spectroscopy.

\section{Conclusions}

In this work we demonstrated a new synthetic strategy to construct the diazatricyclic skeleton of cytisine and related compounds. The easy access of the intermediate $\mathbf{2}$ and the simple transformations provide a short and efficient pathway in total synthesis of cytisine and its derivatives. 


\section{Experimental Section}

General Procedures. All solvents purchased commercially were redistilled and dried before use. TLC was made with Kieselgel $60 \mathrm{~F}_{254}$ Plastikfolien from Merck. Merck Kieselgel 60 (0.040$0.063 \mathrm{~mm}$ ) was used for column chromatography. Melting points were measured on a Büchi SMP 20 apparatus and not corrected. IR spectra: Perkin-Elmer FTIR 1600 spectrometer, ${ }^{1} \mathrm{H}$ and ${ }^{13} \mathrm{C}$ NMR spectra: Bruker AM-300 at 300 and $75 \mathrm{MHz}$, or Varian VXR at 400 and $100 \mathrm{MHz}$, respectively.

Quinolizidine-2,6-dione (2). Prepared according to the Speckamp's protocol, ${ }^{16}$ starting from glutarimide which was N-alkylated with 1-butyn-4-ol in a Mitsunobu reaction, followed by reduction and cyclization to give the target synthon $\mathbf{2}$ in an acceptable yield. The same substance was obtained in the Dieckmann procedure as described. ${ }^{17}{ }^{1} \mathrm{H} \mathrm{NMR}\left(400 \mathrm{MHz}, \mathrm{CDCl}_{3}\right): \delta(\mathrm{ppm})$ $=1.58-2.15 \mathrm{~m}(4 \mathrm{H}), 2.40-2.55 \mathrm{~m}(6 \mathrm{H}), 2.87-2.95 \mathrm{~m}(1 \mathrm{H}), 3.65-3.75 \mathrm{~m}(1 \mathrm{H}), 4.88-4.95 \mathrm{~m}(1$ H). ${ }^{13} \mathrm{C} \mathrm{NMR}\left(\mathrm{CDCl}_{3}, 100 \mathrm{MHz}\right): \delta(\mathrm{ppm})=18.9,29.6,32.7,40.6,41.0,48.1,54.9(10-\mathrm{C})$, 169.5 (6-C), 206.9 (2-C). No NMR data have been reported in the papers ${ }^{16,17}$ cited above.

\section{1-Methyl-7,11-diazatricyclo[7.3.1.0 $\left.{ }^{2,7}\right]$ tridecan-6,13-dione (11-Methyl-13-keto-2,3,4,5-} tetrahydrocytisine) (3a). To the solution of quinolizidine-2,6-dione (2) $(0.5 \mathrm{~g}, 3.0 \mathrm{mmol}$ and $0.18 \mathrm{~g}$ acetic acid in $5 \mathrm{~mL}$ of methanol a mixture of methyl amine $(0.11 \mathrm{~g}, 3.0 \mathrm{mmol})$ and acetic acid $(0.18 \mathrm{~g}, 3.0 \mathrm{mmol})$ in $3 \mathrm{~mL}$ methanol was added dropwise under reflux for six hours. Simultaneously paraformaldehyde $(0.2 \mathrm{~g}, 6.6 \mathrm{mmol})$ was added in six portions in time intervals of 1 hour. After heating for one hour the reaction mixture was kept at room temperature overnight, then evaporated. Under cooling the residue was made alkaline with $30 \%$ potassium hydroxide solution, saturated with potassium carbonate and extracted with $3 \times 20 \mathrm{~mL}$ of dichloromethane. The dichloromethane solution was dried and concentrated in vacuum to give $0.76 \mathrm{~g}$ of the crude product as a yellow oil. $0.40 \mathrm{~g}$ of pure $3 \mathbf{a}(57,4 \%)$ were obtained with column chromatography, using acetone-methanol $2: 3$ eluent. ${ }^{1} \mathrm{H}$ NMR $\left(400 \mathrm{MHz}, \mathrm{CDCl}_{3}\right): \delta(\mathrm{ppm})=$ 1.6-2.7 m (6 H), 2.19 s (N-CH $3,3 \mathrm{H}), 2.9-3.3 \mathrm{~m}(4 \mathrm{H}), 3.7-3.8 \mathrm{~m}(2 \mathrm{H}), 4.1-4.4 \mathrm{~m}(2 \mathrm{H}), 5.13 \mathrm{dd}$ $(1 \mathrm{H}) .{ }^{13} \mathrm{C}$ NMR $\left(\mathrm{CDCl}_{3}, 100 \mathrm{MHz}\right): \delta(\mathrm{ppm})=20.3,27.1,32.9,45.1,47.4,48.1,52.1,57.0$, $59.8,61.1,170.0(6-\mathrm{C}), 212.7$ (13-C). The fumarate of 3a recrystallized from 2-propanol melts at $142-43^{\circ} \mathrm{C}$.

11-Benzyl-7,11-diazatricyclo[7.3.1.0 ${ }^{2,7}$ ]tridecan-6,13-dione (11-Benzyl-13-keto-2,3,4,5-tetrahydrocytisine) (3b). To the solution of quinolizidine-2,6-dione (2) $(6,00 \mathrm{~g}, 358 \mathrm{mmol})$ in methanol (120 mL)a mixture of benzylamine (4,56 g, $420 \mathrm{mmol})$, acetic acid $(2,52 \mathrm{~g}, 420 \mathrm{mmol})$ and methanol $(60 \mathrm{~mL})$ was added dropwise under reflux for 6 hrs. Simultaneously paraformaldehyde $(2,40 \mathrm{~g}, 800 \mathrm{mmol})$ was added to the reaction mixture in six equal portions in time intervals of 1 hour. After standing overnight at room temperature and removal of the solvent in vacuum the residue was made strongly alkaline with $30 \%$ potassium hydroxide solution and saturated with solid potassium carbonate. The mixture was extracted with dichloromethane $(3 \times 50$ $\mathrm{mL})$, the solution was dried $\left(\mathrm{Na}_{2} \mathrm{SO}_{4}\right)$ and evaporated to yield a dark viscous liquid $(12,48 \mathrm{~g})$. 
Trituration with diethyl ether gave $3,81 \mathrm{~g}$ of $\mathbf{3 b}$ as a slightly yellow solid. Flash chromatography of the residue (eluent ethyl acetate - acetone 1:1) furnished an additional portion of 1,68 $\mathrm{g}$ of $\mathbf{3 b}$. Overall yield: $51.4 \% . \mathrm{mp} .133-34^{\circ} \mathrm{C}$. IR (KBr): 3060, 3035, 3025, 1724, 1635. ${ }^{1} \mathrm{H}$ NMR (400 $\left.\mathrm{MHz}, \mathrm{CDCl}_{3}\right): \delta(\mathrm{ppm})=1.6-1.8 \mathrm{~m}(4 \mathrm{H}), 2.20-2.55 \mathrm{~m}(5 \mathrm{H}), 2.71-2.76 \mathrm{~m}(1 \mathrm{H}), 3.02-3.06 \mathrm{~m}$ (1 $\mathrm{H}), 3.15-3.76 \mathrm{~m}(5 \mathrm{H}), 5.20 \mathrm{dd}(1 \mathrm{H}), 7.22-7.37 \mathrm{~m}(5 \mathrm{H}) .{ }^{13} \mathrm{C} \mathrm{NMR}\left(\mathrm{CDCl}_{3}, 100 \mathrm{MHz}\right): \delta(\mathrm{ppm})$ $=20.3,26.9,33.0,47.7(\mathrm{CH}), 48.1,51.9(\mathrm{CH}), 53.9$, $59.9(\mathrm{CH}), 60.2,61.8,127.5,128.3,129.0$, 138.0, 169.3 (6-C), 212.7 (13-C).

11-Benzyl-7,11-diazatricyclo[7.3.1.0 $\left.{ }^{2,7}\right]$ tridecan-6-one (N-benzyl-2,3,4,5-tetrahydrocytisine) (4). A mixture of $\mathbf{3 b}(1.00 \mathrm{~g}, 3.35 \mathrm{mmol})$, hydrazine hydrate $(0.87 \mathrm{~g}, 17,4 \mathrm{mmol})$ and $1.5 \mathrm{~g}$ powdered potassium hydroxide in $10 \mathrm{~mL}$ diethylene glycol was refluxed for 3.5 hours. After diluting with $25 \mathrm{~mL}$ water the mixture was extracted with diethyl ether, the ethereal solution was dried and evaporated to give $0.74 \mathrm{~g}$ crude product as a pale yellow oil. The crystalline product separated out from its cold diisopropyl ether solution to yield 5 (0.44 g, 46.3\%), and recrystallized from hexane. Mp. $96-101^{\circ} \mathrm{C} . R_{\mathrm{f}} 0.89$ (ethyl acetate/isopropyl alcohol/cc. ammonia solution, 45:35:10). ${ }^{1} \mathrm{H}$ NMR (400 $\left.\mathrm{MHz}, \mathrm{CDCl}_{3}\right): \delta(\mathrm{ppm})=1.40-2.50 \mathrm{~m}(9 \mathrm{H}), 2.80-3.10 \mathrm{~m}(4$ $\mathrm{H}), 3.40-3.80 \mathrm{~m}(3 \mathrm{H}), 4.76 \mathrm{~d}(1 \mathrm{H}), 7.20-7.30 \mathrm{~m}(5 \mathrm{H}) .{ }^{13} \mathrm{C} \mathrm{NMR}\left(\mathrm{CDCl}_{3}, 100 \mathrm{MHz}\right): \delta(\mathrm{ppm})=$ 20.3, 26.9, 33.0, $47.7(\mathrm{CH}), 48.1,51.9(\mathrm{CH}), 53.9,59.9(\mathrm{CH}), 60.2,61.8,127.5,128.3,129.0$, 138.0, 169.3 (6-C), 212.7 (13-C).

7,11-Diazatricyclo[7.3.1.0 $\left.{ }^{\mathbf{2}, 7}\right]$ tridecan-6-one $(\mathbf{2 , 3 , 4 , 5 - t e t r a h y d r o c y t i s i n e )}$ (5) $4(0.2 \mathrm{~g}, 0.70$ $\mathrm{mmol})$ in acetic acid $(5 \mathrm{~mL})$ was hydrogenated over $10 \%$ palladium on charcoal under atmospheric pressure for $30 \mathrm{~min}$. After removal of the catalyst, the usual work-up produced 5 (70 $\mathrm{mg}, 51.5 \%$ ) as pale yellow oil. $R_{\mathrm{f}} 0.41$ (ethyl acetate/isopropyl alcohol/cc. ammonia solution, 45:35:10). ${ }^{1} \mathrm{H}$ NMR (400 MHz, $\left.\mathrm{CDCl}_{3}\right): \delta(\mathrm{ppm})=1.55-2.05 \mathrm{~m}(10 \mathrm{H}), 2.35-2.55 \mathrm{~m}(2 \mathrm{H}), 2.85-$ $3.60 \mathrm{~m}(4 \mathrm{H}), 4.55-4.70 \mathrm{~m}(2 \mathrm{H}) .{ }^{13} \mathrm{C} \mathrm{NMR}\left(\mathrm{CDCl}_{3}, 100 \mathrm{MHz}\right): \delta(\mathrm{ppm})=20.3,27.9(\mathrm{CH}), 28.1$, $32.5(\mathrm{CH}), 32.9,33.2,45.8,46.7,50.7,60.0(\mathrm{CH}), 170,6(\mathrm{C}=\mathrm{O})$

11-Benzyl-13 $\alpha$ - and 13 $\beta$-hydroxy-7,11-diazatricyclo[7.3.1.0 $\left.{ }^{2,7}\right]$ tridecan-6-one (6 and 7). To the stirred solution of $\mathbf{3 b}(100 \mathrm{mg}, 0.335 \mathrm{mmol})$ in $5 \mathrm{~mL}$ methanol sodium borohydride $(25 \mathrm{mg}$, $0.67 \mathrm{mmol}$ ) was added at $10^{\circ} \mathrm{C}$. After $30 \mathrm{~min}$ stirring the reaction mixture was acidified with hydrochloric acid, evaporated, made alkaline, and extracted with dichloromethane. After removal of the solvent and treatment of the yellowish residue with diisopropyl ether a mixture of $\mathbf{6}$ and 7 (78 mg, 77.5\%) was obtained as a white solid. IR (KBr): 3386, 3060, 3030, 3010, 1610. Recrystallization from ethyl acetate provided the major isomer 7. ${ }^{1} \mathrm{H} \mathrm{NMR}\left(300 \mathrm{MHz}, \mathrm{CDCl}_{3}\right): \delta$ $(\mathrm{ppm})=1.40-3.60 \mathrm{~m}(15 \mathrm{H}), 2.61 \mathrm{~s}(2 \mathrm{H}), 3.82 \mathrm{t}(1 \mathrm{H}), 4.78 \mathrm{dd}(1 \mathrm{H}), 7.20-7.40 \mathrm{~m}(5 \mathrm{H}) .{ }^{13} \mathrm{C}$ NMR $\left(\mathrm{CDCl}_{3}, 75 \mathrm{MHz}\right): \delta(\mathrm{ppm})=20.2,27.5,33.0,35.5(\mathrm{CH}), 40.5(\mathrm{CH}), 46.2,47.8,53.3,58.8$ $(\mathrm{CH}), 62.9,70.7(\mathrm{CH}), 127.1,128.3,128.9,138.7,169.7$ (6-C).

Minor isomer 6: ${ }^{1} \mathrm{H}$ NMR $\left(300 \mathrm{MHz}, \mathrm{CDCl}_{3}\right): \delta(\mathrm{ppm})=1.40-3.60 \mathrm{~m}(15 \mathrm{H}), 2.62 \mathrm{~s}(2 \mathrm{H}), 3.94 \mathrm{t}$ $(1 \mathrm{H}), 4.08 \mathrm{~d}(1 \mathrm{H}), 7.20-7.40 \mathrm{~m}(5 \mathrm{H}) .{ }^{13} \mathrm{C} \mathrm{NMR}\left(\mathrm{CDCl}_{3}, 100 \mathrm{MHz}\right): \delta(\mathrm{ppm})=20.2,27.0,33.1$, $36.2(\mathrm{CH}), 40.3,40.4(\mathrm{CH}), 51.7(\mathrm{CH}), 52.6,58.8,62.6,70.3(\mathrm{CH}), 128.2,128.3,128.9,138.9$, $169.0(6-\mathrm{C})$. 


\section{Acknowledgements}

The authors' thanks are due Prof. G. Habermehl (School of Veterinary Medicine, Hannover) and Dr. M. Kajtár-Peredy (Central Research Institute of Chemistry, Budapest) for providing the NMR facilities. The authors are indebted to Mrs. M. Marton and Mr. B. Molnár for their valuable technical assistance.

\section{References and Notes}

1. Jensen, A. A.; Frolund, B.; Lijefors, T.; Krogsgaard-Larsen, P. J. Med. Chem. 2005, 48, 4705 and further references therein.

2. G. A. Cordell, An Introduction to Alkaloids: a Bioenergetic Approach, Wiley: New York, 1981

3. Barlow, R. B.; McLeod, L. J. Br. J. Pharmacol. 1969, 35, 161.

4. Barlow, R. B.; Johnson, O. Br. J. Pharmacol. 1989, 98, 799.

5. Canu Boido, C.; Sparatore, F. Farmaco 1999, 54, 438.

6. Canu Boido, C.; Tasso, B.; Boido, V.; Sparatore, F. Farmaco 2003, 58, 265.

7. Coe, J. W.; Brooks, P. R.; Vetelino, M. G.; Wirtz, M. C.; Arnold, E. P.; Huang, J.; Sands, S. B.; Davis, T. I.; Lebel, L. A.; Fox, C. B.; Shrikhande, A.; Heym, J. H.; Schaeffer, E.; Rollema, H.; Lu, Y.; Mansbach, S.; Chambers, L. K.; Rovetti, C. C.; Schulz, D. W.; Tingley, F. D.; O'Neill, B. T. J. Med. Chem. 2005, 48, 3474.

8. Chellapan, S. K.; Xiao, Y.; Tuekmantel, W.; Kellar, K. J.; Kozikowski, J. Med. Chem. 2006, 49, 2673.

9. Bohlmann, F.; Englisch, A.; Ottawa, N.; Sander, H.; Weise, W. Chem. Ber. 1956, 89, 792.

10. Govindachari, T. R.; Rajadurai, S.; Subramanian, M.; Thyagarajan, B. S. J. Chem. Soc. $1957,3839$.

11. van Tamelen, E. E.; Baran, J. S. J. Am. Chem. Soc. 1955, 77, 4944, ibid 1958, 80, 4659.

12. Danieli, B.; Lesma, G.; Passarella, D.; Sacchetti, A.; Silvani, A.; Virdis A. Org. Lett. 2004, $6,493$.

13. Stead, D.; O’Brien, P.; Sanderson, A. J. Org. Lett. 2005, 7, 4459.

14. Stead, D.; O’Brien. P. Tetrahedron 2007, 63, 1885.

15. Scheiber, P.; Nemes, P. Liebigs Ann. Chem. 1994, 1033.

16. Dijkink, J.; Schomaker, H. E.; Speckamp, W. N. Tetrahedron Lett. 1975, 4043.

17. Mandell, L.; Singh, K. P.; Gresham, J. T.; Freeman, W. J. J. Am. Chem. Soc. 1965, 87, 5234.

18. Balázs, B.; Nemes, P.; Scheiber, P.; Tóth, G. J. Mol. Struct. 1999, 475, 153. 